\title{
Application of Azoxystrobin Fungicide Improves Drought Tolerance in Tomato, via Enhancing Physio-Biochemical and Anatomical Feature
}

\author{
Abdelhadi A.I. Ali ${ }^{1}$, El-Sayed M. Desoky ${ }^{2}$, Mostafa M. Rady ${ }^{3}$ \\ ${ }^{1}$ Plant Protection Department, Faculty of Agriculture, Zagazig University, Egypt \\ ${ }^{2}$ Agriculture Botany Department, Faculty of Agriculture, Zagazig University, Egypt \\ ${ }^{3}$ Botany Department, Faculty of Agriculture, Fayoum University, 63514 Fayoum, Egypt \\ Correspondent author Email: mmr02@fayoum.edu.eg; mrady2050@gmail.com
}

Keywords: Azoxystrobin (Amistar), water deficit, tomato, growth, physiological parameters, antioxidant defense system

\begin{abstract}
To investigate whether the fungicide Azoxystrobin improves the potential to maintain physio-biochemical functions, tomato plants were grown under either well-watered and deficit irrigation conditions. Drought-stressed tomato plants showed significant reductions in cell membrane stability (CMS), relative water content (RWC), relative water loss (RWL) and chlorophylls, growth attributes and leaflet and main stem anatomical features, while exhibited increases in contents of proline and total phenols, activities of catalase (CAT), peroxidase (POD) and polyphenol oxidase (PPO), fresh (FW) and dry (DW) weights of roots, and leaflet spongy tissue thickness compared to well-watered control plants. Under full irrigation, Azoxystrobin treatment significantly increased RWC and chlorophyll content, POD and PPO activities, root DW, number of fruits per plant and many features of leaflet and main stem, while significantly decreased CMS and RWL, root, shoot and plant lengths, shoot and plant FW, and stem xylem tissue thickness compared to the control plants sprayed with water. However, Azoxystrobin treatment ameliorated drought stress in tomato plants and significantly increased CMS and free proline content, activities of CAT, POD and PPO, and contents of free and total phenols, and root DW and number of fruits per plant, in addition to spongy tissue thickness of leaflet, but not affected chlorophylls and carotenoids contents, root FW, plant DW and most of anatomical features compared to the stressed plants without Azoxystrobin treatment. These results support that Azoxystrobin foliar application may have a positive effect on well-watered and drought-stressed tomato plants.
\end{abstract}

\section{Introduction}

Tomato is an annual plant transplanted and grown in greenhouses, gardens and often in open fields. Tomato production passed through two critical growth periods, i.e. foliage growth and fruiting stages, during which any dereliction will continue its effect on final yield qualitatively and quantitatively. It is one of the most water demanding crops [1], especially in dry (arid and semi-arid) regions.

Early blight disease of tomato caused by Alternaria solani and A. alternate, is reported to be destructive of Solanaceae plants. Management of this disease is achieved mainly through protective fungicide applications with different mode of actions [2]. Strobilurins are one of the most important classes of agricultural fungicides. Their invention was inspired by a group of fungicidally active natural products [3]. Azoxystrobin is a systemic and broad-spectrum fungicide, which inhibits spore germination and mycelial growth in a wide range of phytopathogenic fungi [4]. Azoxystrobin provides a major alternative to ergosterol biosynthesis inhibitors with broad-spectrum control of cereals, fruits and vegetable diseases [5]. It represents a new option to manage fungicide resistance [6].

Tomato plants treated with Azoxystrobin are looked more vigorous than plants with only conventional fungicides with positive effect on yields, particularly when fungal infection had caused stress [7]. While under drought stress conditions, little information is available on the possibility to use this fungicide for mitigating drought stress conditions, especially for tomato. Application of 
Azoxystrobin is reported to induce a positive influence on water status, water use efficiency (WUE) and yield response in tomato [8,9].

Variation in plant tolerance comes from the diversity of the fungicide detoxification mechanism, varying metabolites and their rate which called physiological selectivity. The metabolism of Azoxystrobin in different plants was similar and complex, resulting in the formation of many metabolites with the parent, Azoxystrobin, being the major component of the residue [10]. A single application of Azoxystrobin (Amistar 25\% SC) on tomato plants at the concentration of $0.05 \%(\mathrm{v} / \mathrm{v}$ ) in water showed that the fungicide concentration was lower in tomato leaves than in fruits. The corresponding half life time periods were 5.90 and 4.07 days [11].

This research work aims to determine the potential effects of foliar application of Azoxystrobin on increasing drought tolerance in tomato plants growing under open greenhouse conditions. To achieve this aim, physiological attributes, photosynthetic pigments, antioxidant defense system (enzymatic and phenolic activities), growth characteristics and anatomical features of leaflet blade and main stem of tomato plants were evaluated under well-watered and drought conditions.

\section{Material and Methods}

\subsection{Plant material, transplanting and growth conditions}

At Zagazig University, Faculty of Agriculture, a pot experiment, repeated 3 times, was carried out during the late summer season beginning of August 2016 to achieve the purpose of the current study. Plastic pots $(20 \mathrm{~cm}$ in diameter), each one was filled with $5 \mathrm{~kg}$ sandy clay soil (1 sand: 1 clay, $\mathrm{v} / \mathrm{v})$. All pots were well-watered before transplanting. Thirty-day-old tomato transplants (cv. 765) were gently removed from their trays and were then transplanted, immediately, at a rate of one healthy seedling per pot.

Before transplanting, $0.8 \mathrm{~g}$ phosphorus fertilizer (calcium super phosphate, $15.5 \% \mathrm{P}_{2} \mathrm{O}_{2}$ ) was added per pot, and then all pots were well watered. After transplanting, $0.8 \mathrm{~g}$ nitrogen (ammonium nitrate, $33 \% \mathrm{~N}$ ) and $0.8 \mathrm{~g}$ potassium (potassium sulfate, $48 \% \mathrm{~K}_{2} \mathrm{O}$ ) fertilizers were added per pot, each in two split doses. The first dose was added after 2 weeks from transplanting and the second was added 2 weeks later. Seedlings were provided with all other necessary agricultural practices as recommended for tomato production.

After transplanting, pots were left 2 weeks as an adaptation period before the beginning of the experimental treatments.

\subsection{Treatments and Azoxystrobin application}

In the $2^{\text {nd }}$ week of adaptation, pots were distributed randomly into two groups; a control group in which plants were sprayed with water, and a comparable group in which plants were sprayed with Azoxystrobin. Each group was represented by 40 pots. Water and Azoxystrobin were sprayed, 3 times in 3 consecutive weeks, and then samples from the two groups were taken as a test to evaluate the potential promotion effects of Azoxystrobin under normal condition (Table 1). Thereafter, each group was divided into two sub-groups to specify treatments; spraying with water + full irrigation (a control), spraying with water + deficit irrigation (65\% of ETc), spraying with Azoxystrobin + full irrigation, and spraying with Azoxystrobin + deficit irrigation. Full irrigation treatment means plants were irrigated at full recovering of crop evapotranspiration; ETc, 3 times weekly, while deficit irrigation (drought condition) treatment means plants were irrigated at $65 \%$ of crop ETc, 3 times weekly. Irrigation treatments were applied for three weeks (from the beginning of the $6^{\text {th }}$ week up to the end of the $8^{\text {th }}$ week). These basic treatments were selected based on our preliminary studies (data not shown). Irrigation of tomato plants with levels under $65 \%$ of ETc was led to the death of plants even with Azoxystrobin due to the aridity of the experimental region. 
Table 1. Effect of azoxystrobin (AZOX) treatment on some physiological traits [cell membrane stability; CMS, relative water content; RWC, excised leaf water retension; ELWR, relative water loss; RWL, and contents of chlorophyll-a; Chl-a, chlorophyll- $b$; Chl- b, chlorophylls- $(a+b)$; Chl- $(a+b)$, total carotenoids; Carot $\left(\mathrm{mg} \mathrm{g}^{-1} \mathrm{FW}\right)$ and free proline $\left(\mu \mathrm{mol} \mathrm{g}^{-1} \mathrm{FW}\right)$ of well-watered tomato plants (at the end of the $5^{\text {th }}$ week after transplanting)

\begin{tabular}{llll}
\hline \multirow{2}{*}{ Parameters } & \multicolumn{2}{l}{ Treatments } & Significance \\
\cline { 2 - 4 } & Control $^{\#}$ & AZOX & $* *$ \\
\hline CMS (\%) & $10.8 \mathrm{~b}$ & $17.3 \mathrm{a}$ & $\mathrm{NS}$ \\
RWC (\%) & 48.2 & 48.2 & $\mathrm{NS}$ \\
ELWR (\%) & 25.2 & 24.0 & $*$ \\
RWL (\%) & $18.4 \mathrm{a}$ & $15.8 \mathrm{~b}$ & $* *$ \\
Chl-a content & $0.60 \mathrm{~b}$ & $1.03 \mathrm{a}$ & $*$ \\
Chl-b content & $0.29 \mathrm{~b}$ & $0.35 \mathrm{a}$ & $* *$ \\
Chl-(a+b) content & $0.89 \mathrm{~b}$ & $1.38 \mathrm{a}$ & $* *$ \\
Carot content & $0.53 \mathrm{~b}$ & $0.95 \mathrm{a}$ & $*$ \\
Proline content & $9.34 \mathrm{~b}$ & $11.02 \mathrm{a}$ & \\
\hline
\end{tabular}

Means marked with the same letter in each row are not significant different $(P<0.05)$ by Duncan's test. ${ }^{\#}$ Control means well-watered plants that not sprayed with azoxystrobin but sprayed with water, NS means not significant, $(*)$ means significant at $P<0.05$, and (**) means significant at $P<0.01$.

Spray treatments of water and Azoxystrobin were applied in another 3 consecutive (the $6^{\text {th }}, 7^{\text {th }}$ and $8^{\text {th }}$ ) weeks, and then samples from the four sub-groups were taken to evaluate the potential promotion effects of Azoxystrobin under drought stress condition (Tables 2-5). The applied concentration was $125 \mathrm{mg}$ a.i. $1^{-1}$ of water, which represents recommended rate of Amistar $25 \% \mathrm{SC}$ $\left(5 \mathrm{~cm}^{3} 10 \mathrm{l}^{-1}\right.$ of water). Water or fungicide solution was sprayed on tomato shoots to run-off by using backpack sprayer with affirmation on washing the sprayer tank three times before each usage.

Samples were harvested at the end of the $5^{\text {th }}$ and at the termination of the experiment; $8^{\text {th }}$ week after transplanting for conducting the physiological, antioxidant defense systems (enzymatic activities and phenolic contents) and anatomical determinations.

Table 2. Effect of irrigation condition and azoxystrobin (AZOX) treatments on some physiological traits [cell membrane stability; CMS, relative water content; RWC, excised leaf water retension; ELWR, relative water loss; RWL, and contents of chlorophyll-a; Chl-a, chlorophyll-b; Chl-b, chlorophylls- $(\mathrm{a}+\mathrm{b})$; Chl- $(\mathrm{a}+\mathrm{b})$, total carotenoids; Carot $\left(\mathrm{mg} \mathrm{g}^{-1} \mathrm{FW}\right)$ and free proline $\left(\mu \mathrm{mol} \mathrm{g} \mathrm{g}^{-1} \mathrm{FW}\right)$ of well-watered and drought-stressed tomato plants (at the end of the $8^{\text {th }}$ week after transplanting)

\begin{tabular}{llllll}
\hline \multirow{2}{*}{ Parameters } & \multicolumn{2}{l}{ Treatments } & & & \\
\cline { 2 - 6 } & Control $^{\#}$ & AZOX & Drought (D) & D+AZOX & Significance \\
\hline CMS (\%) & $14.0 \mathrm{~b}$ & $11.7 \mathrm{c}$ & $9.0 \mathrm{~d}$ & $17.7 \mathrm{a}$ & $* *$ \\
RWC (\%) & $71.7 \mathrm{~b}$ & $79.8 \mathrm{a}$ & $23.3 \mathrm{c}$ & $74.3 \mathrm{ab}$ & $*$ \\
ELWR (\%) & $85.8 \mathrm{ab}$ & $85.1 \mathrm{~b}$ & $88.0 \mathrm{ab}$ & $91.2 \mathrm{a}$ & $*$ \\
RWL (\%) & $51.7 \mathrm{a}$ & $46.9 \mathrm{~b}$ & $26.5 \mathrm{c}$ & $25.2 \mathrm{c}$ & $* *$ \\
Chl-a content & $1.16 \mathrm{ab}$ & $1.24 \mathrm{a}$ & $1.11 \mathrm{~b}$ & $1.09 \mathrm{~b}$ & $*$ \\
Chl-b content & 0.77 & 0.80 & 0.73 & 0.78 & NS \\
Chl-(a+b) content & $1.94 \mathrm{~b}$ & $2.04 \mathrm{a}$ & $1.83 \mathrm{c}$ & $1.87 \mathrm{bc}$ & $*$ \\
Carot content & $1.29 \mathrm{ab}$ & $1.32 \mathrm{a}$ & $1.21 \mathrm{~b}$ & $1.21 \mathrm{~b}$ & $*$ \\
Proline content & $20.6 \mathrm{~b}$ & $20.8 \mathrm{~b}$ & $23.1 \mathrm{a}$ & $24.1 \mathrm{a}$ & $*$ \\
\hline
\end{tabular}

Means marked with the same letter in each row are not significant different $(P<0.05)$ by Duncan's test. ${ }^{\#}$ Control means well-watered plants that not sprayed with azoxystrobin but sprayed with water, NS means not significant, $(*)$ means significant at $P<0.05$, and (**) means significant at $P<0.01$. 
Table 3. Effect of irrigation condition and azoxystrobin (AZOX) treatments on enzymatic [catalase; CAT ( $\mu$ mol $\mathrm{H}_{2} \mathrm{O}_{2} \mathrm{mg}^{-1} \mathrm{FW} \mathrm{min}^{-1}$ ), peroxidase; POD and polyphenol oxidase; PPO (change in absorbance $\left.\mathrm{g}^{-1} \mathrm{~min}^{-1}\right)$ ] activities, and phenolic compounds [free, bound and total phenols $\left.\left(\mathrm{mg} \mathrm{g}^{-1} \mathrm{FW}\right)\right]$ contents in well-watered and drought-stressed tomato plants (at the end of the $8^{\text {th }}$ week after transplanting)

\begin{tabular}{llllll}
\hline \multirow{2}{*}{ Parameters } & \multicolumn{2}{l}{ Treatments } & & \\
\cline { 2 - 6 } & Control $^{\#}$ & AZOX & Drought (D) & D+AZOX & Significance \\
\hline CAT activity & $317 \mathrm{~b}$ & $331 \mathrm{~b}$ & $380 \mathrm{a}$ & $383 \mathrm{a}$ & $* *$ \\
POD activity & $0.58 \mathrm{c}$ & $0.63 \mathrm{~b}$ & $0.78 \mathrm{a}$ & $0.77 \mathrm{a}$ & $*$ \\
PPO activity & $0.29 \mathrm{~b}$ & $0.38 \mathrm{a}$ & $0.40 \mathrm{a}$ & $0.41 \mathrm{a}$ & $*$ \\
Free phenols content & $1.05 \mathrm{~b}$ & $1.10 \mathrm{~b}$ & $1.12 \mathrm{~b}$ & $1.23 \mathrm{a}$ & $*$ \\
Bound phenols content & 0.59 & 0.63 & 0.63 & 0.64 & $\mathrm{NS}$ \\
Total phenols content & $1.64 \mathrm{c}$ & $1.73 \mathrm{bc}$ & $1.78 \mathrm{ab}$ & $1.87 \mathrm{a}$ & $*$ \\
\hline
\end{tabular}

Means marked with the same letter in each row are not significant different $(P<0.05)$ by Duncan's test. ${ }^{\#}$ Control means well-watered plants that not sprayed with azoxystrobin but sprayed with water, NS means not significant, $(*)$ means significant at $P<0.05$, and (**) means significant at $P<0.01$.

Table 4. Effect of irrigation condition and azoxystrobin (AZOX) treatments on growth characteristics of well-watered and drought-stressed tomato plants (at the end of the $8^{\text {th }}$ week after transplanting)

\begin{tabular}{llllll}
\hline \multirow{2}{*}{ Parameters } & \multicolumn{5}{l}{ Treatments } \\
\cline { 2 - 6 } & Control $^{\#}$ & AZOX & Drought (D) & D+AZOX & Significance \\
\hline Root length $(\mathrm{cm})$ & $35.8 \mathrm{a}$ & $29.8 \mathrm{~b}$ & $26.4 \mathrm{c}$ & $29.0 \mathrm{~b}$ & $*$ \\
Shoot length $(\mathrm{cm})$ & $36.4 \mathrm{a}$ & $28.0 \mathrm{c}$ & $29.3 \mathrm{bc}$ & $30.7 \mathrm{~b}$ & $*$ \\
Plant length $(\mathrm{cm})$ & $72.2 \mathrm{a}$ & $57.8 \mathrm{~b}$ & $55.7 \mathrm{~b}$ & $59.7 \mathrm{~b}$ & $* *$ \\
Root fresh weight $(\mathrm{g})$ & $15.0 \mathrm{~b}$ & $15.2 \mathrm{~b}$ & $19.0 \mathrm{a}$ & $15.1 \mathrm{~b}$ & $*$ \\
Shoot fresh weight $(\mathrm{g})$ & $74.8 \mathrm{a}$ & $63.1 \mathrm{~b}$ & $57.1 \mathrm{c}$ & $52.1 \mathrm{~d}$ & $* *$ \\
Plant fresh weight $(\mathrm{g})$ & $89.8 \mathrm{a}$ & $78.3 \mathrm{~b}$ & $76.1 \mathrm{~b}$ & $67.2 \mathrm{c}$ & $*$ \\
Root dry weight $(\mathrm{g})$ & $2.06 \mathrm{~d}$ & $2.80 \mathrm{c}$ & $4.18 \mathrm{a}$ & $3.26 \mathrm{~b}$ & $* *$ \\
Shoot dry weight $(\mathrm{g})$ & $11.9 \mathrm{a}$ & $11.5 \mathrm{a}$ & $10.5 \mathrm{~b}$ & $10.5 \mathrm{~b}$ & $*$ \\
Plant dry weight $(\mathrm{g})$ & $14.0 \mathrm{ab}$ & $13.9 \mathrm{~b}$ & $14.7 \mathrm{a}$ & $13.8 \mathrm{~b}$ & $*$ \\
Number of fruits plant & $1.5 \mathrm{~b}$ & $2.0 \mathrm{a}$ & $1.3 \mathrm{c}$ & $2.0 \mathrm{a}$ & $*$ \\
\hline
\end{tabular}

Means marked with the same letter in each row are not significant different $(P<0.05)$ by Duncan's test. ${ }^{\#}$ Control means well-watered plants that not sprayed with azoxystrobin but sprayed with water, (*) means significant at $P<0.05$, and (**) means significant at $P<0.01$. 
Table 5. Responses of histological features in transverse section of leaflet blade and main stem of well-watered and drought-stressed tomato plants (at the end of the $8^{\text {th }}$ week after transplanting) to treatment with azoxystrobin (AZOX)

\begin{tabular}{llllll}
\hline \multirow{2}{*}{ Parameters $(\mu \mathrm{m})$} & \multicolumn{5}{l}{ Treatments } \\
\cline { 2 - 6 } & Control $^{\#}$ & AZOX & Drought (D) & D+AZOX & Significance \\
\hline Leaflet anatomy & & & & & \\
Upper epidermis thickness & $39.7 \mathrm{a}$ & $41.0 \mathrm{a}$ & $30.0 \mathrm{c}$ & $36.6 \mathrm{~b}$ & $*$ \\
Lower epidermis thickness & $38.0 \mathrm{ab}$ & $39.0 \mathrm{a}$ & $31.0 \mathrm{c}$ & $35.6 \mathrm{~b}$ & $*$ \\
Blade thickness & $330 \mathrm{~b}$ & $400 \mathrm{a}$ & $300 \mathrm{c}$ & $310 \mathrm{bc}$ & $*$ \\
Palisade tissue thickness & $110 \mathrm{~b}$ & $120 \mathrm{a}$ & $100 \mathrm{c}$ & $102 \mathrm{bc}$ & $*$ \\
Spongy tissue thickness & $120 \mathrm{c}$ & $200 \mathrm{a}$ & $140 \mathrm{~b}$ & $141 \mathrm{~b}$ & $* *$ \\
Diameter of vessel average & $43.3 \mathrm{~b}$ & $46.6 \mathrm{a}$ & $30.0 \mathrm{~d}$ & $33.3 \mathrm{c}$ & $*$ \\
Phloem tissue thickness & $121 \mathrm{a}$ & $130 \mathrm{a}$ & $90 \mathrm{c}$ & $100 \mathrm{~b}$ & $*$ \\
Xylem tissue thickness & $160 \mathrm{a}$ & $170 \mathrm{a}$ & $109 \mathrm{~b}$ & $160 \mathrm{a}$ & $*$ \\
Midvein thickness & $1009 \mathrm{~b}$ & $1109 \mathrm{a}$ & $749 \mathrm{c}$ & $949 \mathrm{~b}$ & $* *$ \\
Midvein width & $1309 \mathrm{a}$ & $1349 \mathrm{a}$ & $849 \mathrm{c}$ & $1099 \mathrm{~b}$ & $* *$ \\
& & & & & $*$ \\
Main stem anatomy & & & & & $*$ \\
Epidermis thickness & 39.0 & 40.0 & 37.6 & 38.1 & NS \\
Cortex thickness & $220 \mathrm{~b}$ & $310 \mathrm{a}$ & $110 \mathrm{~d}$ & $160 \mathrm{c}$ & $* *$ \\
Phloem tissue thickness & $240 \mathrm{~b}$ & $300 \mathrm{a}$ & $160 \mathrm{~d}$ & $220 \mathrm{c}$ & $* *$ \\
Xylem tissue thickness & $550 \mathrm{a}$ & $500 \mathrm{~b}$ & $400 \mathrm{c}$ & $490 \mathrm{~b}$ & $*$ \\
Diameter of vessel average & $73.3 \mathrm{a}$ & $76.6 \mathrm{a}$ & $56.6 \mathrm{c}$ & $66.6 \mathrm{~b}$ & $*$ \\
Stem diameter & $3439 \mathrm{~b}$ & $4616 \mathrm{a}$ & $3077 \mathrm{c}$ & $3276 \mathrm{bc}$ & $*$ \\
Hollow pith diameter & $1539 \mathrm{~b}$ & $2534 \mathrm{a}$ & $1358 \mathrm{c}$ & $1484 \mathrm{bc}$ & $*$ \\
\hline
\end{tabular}

Means marked with the same letter in each row are not significant different $(P<0.05)$ by Duncan's test. ${ }^{\#}$ Control means well-watered plants that not sprayed with azoxystrobin but sprayed with water, NS means not significant, $(*)$ means significant at $P<0.05$, and $(* *)$ means significant at $P<0.01$.

\subsection{Cell membrane stability (CMS)}

The CMS was determined according to the method described by [12] using the upper full expanded leaves from each treatment. Twenty leaf discs $(1 \mathrm{~cm}$ in diameter) were taken from leaves and washed with deionized water. For desiccation treatment, ten leaf discs were flooded in $10 \mathrm{ml}$ of $30 \%$ polyethylene glycol (PEG6000) in $15 \mathrm{ml}$ test tubes for $24 \mathrm{~h}$ at $10{ }^{\circ} \mathrm{C}$. For control treatment, ten leaf discs were flooded in distilled water. Thereafter, the treatment and control leaf discs were washed with deionized water and $10 \mathrm{ml}$ of deionized water was added to each tube. The tubes were maintained for $24 \mathrm{~h}$ at $10^{\circ} \mathrm{C}$, and then conductivity of the solutions was determined by electrical conductivity meter. Finally, the tubes were boiled in a water bath for $60 \mathrm{~min}$, cooled to room temperature, and the conductivity of the solutions was recorded again. Percent of CMS value for leaf tissues was calculated using the following equation:

$$
\operatorname{CMS}(\%)=\left(1-\frac{(1-T 1 / T 2)}{(1-C 1 / C 2)}\right) \times 100
$$

where: $T_{1}$ and $T_{2}$ are the first and second (pre and after boiling, respectively) measurements of the conductivity of solutions, and $\mathrm{C}_{1}$ and $\mathrm{C}_{2}$ are the respective values for the controls. 


\subsection{Relative water content ( $R W C$ )}

Four upper full expanded leaves were collected from each treatment and immediately weighted to record fresh weight $(\mathrm{FW})$. Then, were placed in distilled water for 4 hours at $25 \pm 2{ }^{\circ} \mathrm{C}$ and weighed again to record turgid weight (TW). Leaves were then subjected to drying oven at $70^{\circ} \mathrm{C}$ until constant weight and the dry weight (DW) values were recorded. The RWC was calculated using the following equation suggested by [13]

$$
\mathbf{R W C}(\%)=\frac{\mathrm{FW}-\mathrm{DW}}{\mathrm{TW}-\mathrm{DW}} \times \mathbf{1 0 0}
$$

\subsection{Excised leaf water retention (ELWR)}

Four upper full expanded leaves were collected and weighed to record fresh weight (FW), and then left for $4 \mathrm{~h}$ to wilt at $25^{\circ} \mathrm{C}$ and reweighed (WW4h). ELWR was calculated using the following formula according to [14]

$$
\operatorname{ELWR}(\%)=\left[1-\frac{\mathrm{FW}-\mathrm{WW} 4 \mathrm{~h}}{\mathrm{FW}}\right] \times \mathbf{1 0 0}
$$

\subsection{Relative water loss (RWL)}

Four upper full expanded leaves were sampled for each treatment and samples were weighed to record fresh weight (FW), wilted for 4 hours at $35^{\circ} \mathrm{C}$ in incubator and reweighed (WW $4 \mathrm{~h}$ ), and then oven dried at $72{ }^{\circ} \mathrm{C}$ until constant weight and weighed (DW). The RWL was calculated using the following formula according to [15]

$$
\mathbf{R W L}(\%)=\frac{(\mathrm{FW}-\mathrm{WW} 4 \mathrm{~h})}{(\mathrm{FW}-\mathrm{DW})} \times \mathbf{1 0 0}
$$

\subsection{Chlorophyll and carotenoids contents determinations}

Leaf photosynthetic pigments; chlorophyll-a (Chl-a), chlorophyll-b (Chl-b) and carotenoids (Carot) were measured by the method described by [16]. Pigments were extracted from upper full expanded leaf samples by pure acetone and extracts were filtered. The optical density (E) of the filtrate was determined Spectrophotometrically at $662,644,440.5 \mathrm{~nm}$ for pigments that were calculated as $\mathrm{mg} \mathrm{g}^{-1} \mathrm{FW}$ using the formulae adopted by [17] as follows:

$\mathrm{Chl}-\mathrm{a}=\left(9.784 \times \mathrm{E}_{662}\right)-\left(0.99 \times \mathrm{E}_{644}\right)$

$\mathrm{Chl}-\mathrm{b}=\left(21.426 \times \mathrm{E}_{644}\right)-\left(4.65 \times \mathrm{E}_{662}\right)$

Carot $=\left(4.695 \times \mathrm{E}_{440.5}\right)-(0.268 \times \mathrm{Chl}-\mathrm{a}+\mathrm{Chl}-\mathrm{b})$

\subsection{Proline content (PC) determination}

Using upper full expanded leaves, proline was determined according to the method of [18]. Samples $(0.5 \mathrm{~g}$ of each) were grinded with $10 \mathrm{ml}$ of $3 \%$ sulfosalicylic acid, and the homogenates were filtered. Two $\mathrm{ml}$ of glacial acetic acid and $2.0 \mathrm{ml}$ acid ninhydrin reagent were added to a $2.0 \mathrm{ml}$ of the filtrate, and the mixture was then shaken by hand and incubated in boiling water bath for $1 \mathrm{~h}$. Thereafter, it was transferred to ice bath and cooled to room temperature. Four ml of Toluene was added to the mixture and the absorbance of the upper toluene layer after separation was measured at $520 \mathrm{~nm}$ using spectronic 20-D spectrophotometer.

\subsection{Determination of catalase (EC 1.11.1.6) activity}

Measurement of catalase activity was made according to the perborate method of [19]. Leaf tissue $(0.5 \mathrm{~g})$ was crushed in a mortar with $5 \mathrm{ml}$ of $\mathrm{pH} 6.8$ phosphate buffer, and the macerate was then squeezed through muslin. A series of flasks containing $5 \mathrm{ml}$ of $1.5 \%$ sodium perborate $+1.5 \mathrm{ml}$ phosphate buffer ( $\mathrm{pH}$ 6.8) were prepared. At zero time, $1 \mathrm{ml}$ of the macerate was pipetted into each flask. The reaction was stopped by rapidly adding $10 \mathrm{ml} 2 \mathrm{~N}$ sulfuric acid. One drop of manganese chloride $1 \%$ was added for each flask and titration was carried out by means of potassium permanganate $(0.05 \mathrm{~N})$ using an appropriate blank for each series. 


\subsection{Determination of peroxidase (EC 1.11.1.7) activity}

One g of sample (upper full expanded leaves) was crushed well in $2 \mathrm{ml}$ of $0.1 \mathrm{M}$ sodium phosphate buffer ( $\mathrm{pH}$ 7.1). The homogenate was filtered through Whatman No.1 filter paper. The suspension was centrifuged at $6000 \mathrm{rpm}$ at $4{ }^{\circ} \mathrm{C}$ for $20 \mathrm{~min}$ and stored at $-18^{\circ} \mathrm{C}$ until use. Peroxidase activity was analyzed spectrophotometrically [20]. The reaction mixture consisted of $1.5 \mathrm{ml}$ of $0.05 \mathrm{M}$ pyrogallol, $100 \mu \mathrm{l}$ of enzyme extract and $0.5 \mathrm{ml}$ of $1 \% \mathrm{H}_{2} \mathrm{O}_{2}$. The reaction mixture was incubated at room temperature $(28 \pm$ $2{ }^{\circ} \mathrm{C}$ ). Color density was measured in a spectrophotometer at $425 \mathrm{~nm}$ every $30 \mathrm{sec}$ [21]. The enzyme activity was expressed as changes in the absorbance $\min ^{-1} \mathrm{~g}^{-1}$ of fresh leaf tissue.

\subsection{Determination of polyphenol oxidase (EC 1.14.18.1) activity}

Polyphenol oxidase activity was determined by the procedure described by [22] using upper full expanded leaves. The reaction mixture consisted of $1.5 \mathrm{ml}$ of $0.1 \mathrm{M}$ sodium phosphate buffer (pH 6.5) and $100 \mu \mathrm{l}$ of the enzyme extract. To start the reaction, $200 \mu \mathrm{l}$ of $0.01 \mathrm{M}$ catechol was added and the activity was expressed as changes in absorbance at $495 \mathrm{~nm} \mathrm{~min}^{-1} \mathrm{~g}^{-1}$ of fresh leaf tissue.

\subsection{Determination of phenolic compounds contents}

Phenolic contents were colorimetrically determined using the folin reagent according to [23]. Two $\mathrm{g}$ from upper fully expanded leaves were crashed and immersed in $25 \mathrm{ml}$ of $70 \%$ ethanol in brown bottles, and were then stored in dark at room temperature. After a month, ethanolic extraction was dried at room temperature, and then transported quantitatively into $5 \mathrm{ml}$ of $50 \%$ isopropanol and stored in vials at $1{ }^{\circ} \mathrm{C}$. For total phenols content, a reaction mixture consisted of $1 \mathrm{ml}$ extraction and $0.25 \mathrm{ml} \mathrm{HCl}$ was boiled in a water bath for $10 \mathrm{~min}$, and then cooled. One $\mathrm{ml}$ of Folin-Denis reagent and $6 \mathrm{ml}$ of $20 \% \mathrm{Na}_{2} \mathrm{CO}_{3}$ were added. The mixture was completed to $10 \mathrm{ml}$ with distilled water and the color density was measured at $520 \mathrm{~nm}$. Tannic acid was used as a standard compound. For free phenols content, a reaction mixture consisted of $1 \mathrm{ml}$ of extracted sample, $1 \mathrm{ml}$ of distilled water, 1 of $\mathrm{ml}$ Folin-Denis reagent and $3 \mathrm{ml}$ of $20 \% \mathrm{Na}_{2} \mathrm{CO}_{3}$, was adjusted to a final volume of $10 \mathrm{ml}$ with distilled water. Free phenols content was then measured as mentioned before for total phenols content. For bound phenols content, the difference between total and free phenols contents gives the content of bound phenols.

\subsection{Growth and fruit yield parameters}

At the endpoint (end of 8 weeks after transplanting), 10 plants from each treatment were selected randomly to measure plant height, shoot and root lengths, fruit number per plant, fresh and dry $\left(70^{\circ} \mathrm{C}\right.$ for $48 \mathrm{~h}$ or until a constant weight) weights of shoots and roots. Fruits number was taken at the end of the experiments (at the $56^{\text {th }}$ day; the $8^{\text {th }}$ week after transplanting, with the beginning of the fruiting process and before its completion).

\subsection{Anatomical Responses}

Specimens from a blade of the selected leaflet and main stem were obtained from various treatments. The specimens were killed and fixed in FAA (10 $\mathrm{ml}$ of formalin, $5 \mathrm{ml}$ of glacial acetic acid, and $85 \mathrm{ml}$ of ethyl alcohol 70\%), washed in 50\% ethyl alcohol, dehydrated in butyl alcohol series and cleared by xylene and absolute alcohol. Finally, specimens were embedded in liquefied pure paraffin wax. Sections at thickness of $14 \mu \mathrm{m}$ were cut. Paraffin ribbons were mounted on slides, stained with Safranin and Light green, then mounting in Canada balsam [24]. The prepared slides were examined with a light microscope equipped with a digital camera (Canon Power Shot S80) connected to a computer. Sections were photographed and examined to detect histological manifestations of the chosen treatments and micrograph. All parameters measured using calibrated micrometer slide under light microscope.

\subsection{Experimental layout and statistical analysis of data}

Experimental treatments were arranged in a completely randomized blocks design. The experimental data were analyzed statistically by one-way ANOVA. The mean values of treatments 
were separated by Duncan's multiple range test $(P<0.05$ and 0.01$)$ according to [25] using CoStat 6.4 software package.

\section{Results}

3.1. Using 35-day-old tomato plants after transplanting to test the potential improving effects of Azoxystrobin under normal (well-watered) condition

Data in Table 1 show that spraying tomato plants with Azoxystrobin significantly increased some physiological attributes; cell membrane stability and contents of chlorophyll-a (Chl-a), chlorophyll-b (Chl-b), chlorophylls- $(a+b)[C h l-(a+b)]$, total carotenoids (Carot) and free proline. These increases were $60.2,71.7,20.7,55.1,79.2$ and $18.0 \%$, respectively compared to those in plants sprayed with water under normal (well-watered) conditions. Per contra, relative water loss (RWL) was significantly decreased (by 14.1\%), while relative water content (RWC) and excised leaf water retension (ELWR) were not affected by spraying plants with Azoxystrobin.

\subsection{Using 56-day-old tomato plants after transplanting to test the potential improving effects of Azoxystrobin under drought (deficit irrigation) condition}

Under normal (well-watered) condition, foliar spray with Azoxystrobin to tomato plants significantly increased RWC by $11.3 \%$ and $\mathrm{Chl}-(\mathrm{a}+\mathrm{b})$ content by $5.2 \%$ (Table 2 ), peroxidase (POD) activity by $8.6 \%$ and polyphenol oxidase (PPO) activity by $31.0 \%$ (Table 3 ), root dry weight (DW) by $35.9 \%$ and number of fruits per plant by $33.3 \%$ (Table 4 ), and many features of leaflet (blade thickness by $21.2 \%$, palisade tissue thickness by $9.1 \%$, spongy tissue thickness by $66.7 \%$, average diameter of vessels by $7.6 \%$ and midvein thickness by $9.9 \%$ ) and main stem (cortex thickness by $40.9 \%$, phloem tissue thickness by $25.0 \%$, stem diameter by $34.2 \%$ and hollow pith diameter by $64.7 \%$ ) (Table 5) compared to the control plants sprayed with water. Contrariwise, Azoxystrobin treatment significantly decreased CMS by $16.4 \%$ and RWL by $9.3 \%$ (Table 2 ), root length by $16.8 \%$, shoot length by $23.1 \%$, plant length by $19.9 \%$, shoot fresh weight (FW) by $15.6 \%$ and plant FW by $12.8 \%$ (Table 4 ), and the stem anatomy feature of xylem tissue thickness by $9.1 \%$ (Table 5) compared to the control plants. However, the following parameters were not affected by Azoxystrobin treatment: ELWR, Chl-a content, Chl-b content and total carotenoids content (Table 2), catalase (CAT) activity, and free, bound and total phenols contents (Table 3), root FW, shoot DW and plant DW (Table 4), and some features of leaflet (upper epidermis thickness, lower epidermis thickness, phloem tissue thickness, xylem tissue thickness and midvein width) and main stem (epidermis thickness and average diameter of vessels) (Table 5).

Deficit irrigation (drought)-stressed tomato plants showed significant reductions in most tested parameters of physiology, growth and leaflet and main stem anatomical features (Tables 2-5). These reductions were $35.7 \%$ for CMS, $67.5 \%$ for RWC, $48.7 \%$ for RWL, $5.7 \%$ for Chl- $(\mathrm{a}+\mathrm{b}), 26.3 \%$ for root length, $19.5 \%$ for shoot length, $22.9 \%$ for plant length, $23.7 \%$ for shoot $\mathrm{FW}, 15.3 \%$ for plant FW, $11.8 \%$ for shoot DW, $13.3 \%$ for number of fruits per plant, $24.4 \%$ for upper epidermis thickness of leaflet, $18.4 \%$ for lower epidermis thickness of leaflet, $9.1 \%$ for leaflet blade thickness, $9.1 \%$ for leaflet palisade tissue thickness, $30.7 \%$ for leaflet diameter of vessels, $25.6 \%$ for leaflet phloem tissue thickness, $31.9 \%$ for leaflet xylem tissue thickness, $25.8 \%$ for leaflet midvein thickness, $35.1 \%$ for leaflet midvein width, $50.0 \%$ for stem cortex thickness, $33.3 \%$ for stem phloem tissue thickness, $27.3 \%$ for stem xylem tissue thickness, $22.8 \%$ for stem diameter of vessels, $10.5 \%$ for stem diameter, and $11.8 \%$ for stem hollow pith diameter compared to the well-watered control plants. In contrast, drought-stressed tomato plants showed significant increases in proline content by $12.1 \%$, CAT activity by $19.9 \%$, POD activity by $34.5 \%$, PPO activity by $37.9 \%$, total phenols content by $8.5 \%$, root FW by $26.7 \%$, root DW by $102.9 \%$, and leaflet spongy tissue thickness by $16.7 \%$. On the other hand, there are some parameter that were not affected by drought stress, e.g., ELWR, contents of Chl-a, Chl-b, total carotenoids, and free and bound phenols, plant DW and stem epidermis thickness.

However under drought stress, spraying tomato plants with Azoxystrobin significantly increased some of the physiological attributes (CMS by $26.4 \%$ and free proline content by $17.0 \%$ ), 
antioxidative defense systems (CAT activity by $20.8 \%$, POD activity by $32.8 \%$, PPO activity by $41.4 \%$, free phenols content by $17.1 \%$ and total phenols content by $14.0 \%$ ), and growth traits (root DW by $58.3 \%$ and number of fruits per plant by $33.3 \%$ ), in addition to spongy tissue thickness of leaflet by $17.5 \%$ compared to the control plants sprayed with water. In contrast, Azoxystrobin foliar treatment significantly decreased another some of the physiological attributes (RWL by 51.3\%), growth characteristics (root length by $19.0 \%$, shoot length by $15.7 \%$, plant length by $17.3 \%$, shoot FW by $30.3 \%$, plant FW by $25.2 \%$ and shoot DW by $11.8 \%$ ), and anatomical features of leaflet (upper epidermis thickness by $7.8 \%$, average diameter of vessels by $23.1 \%$, phloem tissue thickness by $17.4 \%$ and midvein width by $16.0 \%$ ) and main stem (cortex thickness by $27.3 \%$, phloem tissue thickness by $8.3 \%$, xylem tissue thickness by $10.9 \%$ and average diameter of vessels by $9.1 \%$ ) compared to water foliar treatment. While others of the physiological parameters (RWC, ELWR, and the contents of Chl-a, Chl- b, total Chl- $(\mathrm{a}+\mathrm{b})$ and total carotenoids), growth traits (root FW and plant DW) and anatomical features of leaflet (lower epidermis thickness, blade thickness, palisade tissue thickness, xylem tissue thickness and midvein thickness) and main stem (epidermis thickness, stem diameter and hollow pith diameter), in addition to the content of bound phenols were not affected by Azoxystrobin treatment.

\section{Discussion}

Impairing crop plant growth and limiting its production, water deficit, particularly in arid and semi-arid regions, considers as one of the major constraints that threats the agricultural productions nowadays and may cause more severe in future due to continuous climate changes. In the present study, a deficit of irrigation water caused a reduction in tomato growth (Table 4), disruptions in many physio-biochemical attributes, the most important of which were plant/cell water relations and leaf photosynthetic pigments (Table 2), and negative modifications in leaf and stem anatomy (Table 5).

These negative effects of water deficit stress are attributed to a decrease of cell division, cell elongation, and differentiation affected due to impaired enzyme activities, loss of cell turgor, and decreased energy supply. In addition to that plants tend to partially close their stomata under drought stress causing reductions in photosynthesis rate and membrane damage, and disturbances in activity of various enzymes, especially enzymes involved in ATP synthesis [26, 27, 28]. Plant water relations attributes such as relative water content (RWC), leaf water, osmotic and pressure potentials, and transpiration rate are negatively affected under water deficit due to a shortage in water supply [29, 30]. Impaired activities of essential photosynthetic enzymes, the most important one is ribulose-1,5bisphosphate carboxylase/oxygenase (Rubisco) is responsible for the decrease of photosynthesis rate under drought [27, 31]. Progressive downregulation and metabolic processes inhibition decrease ribulose-1,5-bisphosphate (RuBP) contents, of which conversion to 3-phosphoglyceric acid (3-PGA) will decrease with reducing leaf RWC under drought [32]. At moderate water deficit stress, Rubisco acts as oxygenase due to higher internal $\mathrm{O}_{2}$ than $\mathrm{CO}_{2}$ contents due to stomatal closure, and increase photorespiration at the expense of carbon-fixation [33]. Photorespiration may be beneficial under drought stress due to its involving in energy dissipation and thus it reduces [32]. In addition, it produces glycine (amino acid) to use for synthesis of glutathione as an important component of antioxidant defense [34], and it also enhances the RuBP supply to Calvin cycle [35]. As reported, low $\mathrm{CO}_{2}$ influx under drought stress deteriorated RuBP contents, Rubisco activities or ATP synthesis which downregulate carbon fixation, consequently, oxidation of reduced NADPH in the Calvin cycle is decreased, and consequently, $\mathrm{NADP}^{+}$(primary electron acceptor) is not sufficiently available [32]. Plants exposed to drought stress leads to increased oxidative stress with ROS (e.g., $\mathrm{O}_{2}{ }^{\cdot-},{ }^{1} \mathrm{O}_{2}, \mathrm{H}_{2} \mathrm{O}_{2}$ and $\mathrm{OH}^{-}$) overproduction that are highly reactive, toxic and deteriorate normal plant metabolism through oxidative causing damages to proteins, lipids, carbohydrates, and DNA [36, 37]. The major sites of ROS generation are found in both chloroplasts (e.g., PSI and PSII) and mitochondria (e.g., complex I, ubiquinone and complex III of electron transport chain; ETC) [38]. Consequently, diminished activities of essential enzymes and ATP synthesis due to oxidative damage lead to minimize photosynthetic and respiratory activities. 
Plants adopt a lot of mechanisms to tolerate drought stress, some of them are found in our results such as reduced water loss (Table 2) by increased diffusive resistance, increased water uptake with prolific and deep root systems (Table 4), increased low-molecular-weight osmolytes such as proline (Table 2) sustaining cellular functions under water deficit stress. Higher cell membrane stability (CMS; Table 2), elevated phenolic compound contents and enzymatic antioxidants activities (Table 3) and increased spongy tissue thickness (Table 5) modulate plant responses to drought stress. In addition to reported earlier, plants exhibit several morphological and physio-biochemical adaptations at subcellular, cellular and organ levels to survive under drought stress. However, drought stress tolerance is a complex phenomenon associated with stomatal regulation, hormonal balances, antioxidant defense system, osmotic adjustment, root system and maintenance of tissue water contents, in addition to cuticle thickness etc. Drought escape (the ability of a plant to complete its life cycle before the beginning of drought) and avoidance (the ability of a plant to sustain high plant water status or cellular hydration under drought; [39]) are also of important mechanisms for drought tolerance.

The most important plant challenges with drought undergo adaptive mechanisms at molecular levels such as up- and downregulation of many gene transcripts and accumulation of stress proteins [40]. Underwater deficit stress, a considerable rise in CDSP 32 (chloroplastic drought-induced stress protein) mRNA and protein protects chloroplast from drought-induced oxidative damage [41]. In addition, aquaporins (an important group of intrinsic membrane proteins) are able to regulate hydraulic conductivity of membranes [42]. Many dehydration-responsive element-binding genes are also involved in signaling pathways in response to water deficit stress [43]. The dehydrationresponsive element/C-repeat (DRE/CRT) cis-acting element and its DNA-binding protein are a major transcription system that modulates ABA-independent gene expression in response to drought stress and includes dehydration-responsive element binding proteins (DREB)/C-repeat binding factors (CBF) family of proteins. DREB2 subclass of DREB/CBF family proteins are expressed under drought stress to articulate genes involved in stress tolerance [44]. Signal transduction pathways are also induced in plants under water deficit stress to regulate plant growth. An early-warning response mechanism exists in plant roots to activate the hydrogen pump ATPase protein $\left(\mathrm{H}^{+}\right.$-ATPase $)$on plasma membrane of root hairs before a substantial decline in tissue RWC of plant. The activation of root hair cell plasma membrane $\mathrm{H}^{+}$-ATPase stimulates magnified biosynthesis of key osmolytes such as leaf proline and glycine betaine to maintain the water content in plants. Moreover, interspecific and intraspecific differences in the timing of inducing early responses may exist to initiate warming responses to drought stress [45]. It has been concluded that, polyamines (PAs) associate with the response of plants to drought stress by signaling [46]. Ornithine decarboxylase (TcODC), arginine decarboxylase (TcADC), S-adenosylmethionine decarboxylase (TcSAMDC), spermidine synthase (TcSPDS), and spermine synthase (TcSPMS) are the expression patterns of genes encoding enzymes involved in PAs in plant leaves. Expression of TcODC, TcADC, and TcSAMDC is induced at the start of drought which modulates stomatal conductance, photosynthesis, photosystem II efficiency, and leaf water potential. Induction of TcSAMDC in leaves is most closely correlated with changes in water potential. The earliest measured responses to drought are enhanced expression of TcADC and TcSAMDC in plant roots along with decreases in stomatal conductance, photosynthesis, and PS II efficiency due to elevated levels of PAs; putrescine, spermidine and spermine [46].

Although plants have many endogenous mechanisms to survive under abiotic stress conditions including water deficit stress, in most cases they need exogenous help to support their mechanisms. In the present study, a fungicide Azoxystrobin was used as foliar spray to potentially increase drought stress tolerance in tomato plants. As shown in our data, proline content was significantly increased by application of Azoxystrobin supporting plant osmoprotectants concentrations to tolerate drought conditions. However, plants might be already surrendered to chemical stress resulted from azoxystrobin degradation in the plant as a xenobiotic. In this concern, [47]. have concluded that at higher concentrations, phytotoxicity of Azoxystrobin varied with host genotype. Among the tested plants, Catjang (Vigna unguiculata subsp. cylindrical) was most sensitive to the fungicide. The fungicide at different concentrations significantly decreased community respiration and gross primary 
productivity. However, the net primary productivity was significantly increased by Azoxystrobin treatment up to $0.0073 \mu \mathrm{g}$ a.i. $\mathrm{ml}^{-1}$. They have added that increase in fungicide concentration and incubation period of treated leaf tissue resulted in increased electrolyte leakage measured by increased electrical conductivity. In addition, [48] have noticed that using Strobilurins to improve water status of wheat grown under drought conditions by the decrease of the conductance of water through the epidermis and lower rate of transpiration, lower intercellular carbon dioxide concentration, and lower net rate of photosynthesis. They have also mentioned that the probable mechanism for the photosynthetic effects may be caused either by Strobilurin fungicides acting directly on ATP production in guard cell of mitochondria or by stomata responding to Strobilurin-induced changes in mesophyll photosynthesis. In addition, application of Azoxystrobin improved tomato water status, especially under water stress conditions in terms of osmotic potential, relative water content and crop water stress index as a result of improving the formation of ABA [8]. All inspected reviews did not refer to probable action of water stress tolerance but it proved a phytotoxic effect invisible on plant parts, however, it detected on physiological level. Variation in plant tolerance comes from the diversity of the fungicide detoxification mechanism, varying metabolites and their rate which called physiological selectivity. The main metabolic pathway for Azoxystrobin in plant ended with the compound 2-hydroxybenzonitrile which has an herbicidal effect. Information on Azoxystrobin metabolism is studied [49, 50, 51].

In the present study, CMS did not record a significant difference between irrigation treatments or Azoxystrobin spraying. Also, Azoxystrobin application caused a significant increase of RWC and excised leaf water retention (ELWR) in tomato leaves, while caused a significant reduction of relative water loss (RWL) under water deficit stress. These measures represent beneficial mechanisms for tomato plants to tolerate water deficit stress. In contrast, 6 Azoxystrobin sprays may represent a toxic effect on some resulted metabolites, but the plant may be developed a detoxification mechanism leading to stability of parameters values and to vanish the deductions claiming the potential of Azoxystrobin to raise the drought tolerance. In this connection, [7] have noticed that tomato plants sprayed with Azoxystrobin look more vigorous than plants without Azoxystrobin, and the effect on yields was positive, particularly when fungal infection had caused stress. Several studies [52, 53, 54] have reported that the physiological effects of Pyraclostrobin (a Strobilurin like Azoxystrobin) on plants as enhancement of nitrate-reductase activity, change in hormonal balance, water conservation and delayed senescence were reflected in improved plant yield.

[47] have observed that Azoxystrobin causes no visible phytotoxic when applied with a recommended dose. On bean leaves, [55] have stated that Azoxystrobin exhibits no effect on chlorophylls and nitrogen contents. In addition, [56] have reported that foliar application of Azoxystrobin under drought conditions had positive influences on plant water status, water use efficiency and yields in tomato. But, anti-water stress should be possessed a steady physiological response which did not fluctuate with a continuing application, as shown in our results, and did not interfere with physiological function for increasing plant production and yield, as well as, it had no effect on photosynthesis and respiration. In contrast, [57] have indicated that Azoxystrobin was shown to be phytotoxic in some situations during controlling Aphanomyces root rot caused by Aphanomyces euteiches, which consider a serious disease in certain green bean (Phaseolus vulgaris).

Our results also show that Azoxystrobin treatment, drought condition and integrative Azoxystrobin + drought treatment significantly increased catalase (CAT), peroxidase (POD) and polyphenol oxidase (PPO) activities exhibiting vigor enzymes response to drought condition comparing with well-irrigated treatment, and the same trend was observed with free and total phenols contents. These enzymatic and non-enzymatic antioxidants have been shown to support the role for detoxification enzymes, increasing phenols that the main part of Azoxystrobin structure and preparing for the second phase in Azoxystrobin metabolism which called conjugation phase that represented in bound phenols, this assumption ascertained by interaction between irrigation and Azoxystrobin factors. Degradation rate of Azoxystrobin may be increased under drought condition, otherwise, it is unlikely that Azoxystrobin has a role in increased drought tolerance or induced plant defense 
mechanism directly, but, its metabolites may cause fluctuation in different phenols depending on plant and its detoxification enzymes.

It has been obviously shown (Table 4) that Azoxystrobin treatment reduced tomato plant size to reduce water loss from drought-stressed plant, and this was gathered with increasing total root volume by Azoxystrobin treatment to increase the root capacity to absorb more water under water deficit stress. This was reflected in increased root dry weight and maintained plant dry weight to increase tomato fruit number under the studied stress. These two mechanisms occurred by Azoxystrobin treatment are very important for tomato plants to survive under drought stress.

Shoot system represents the contact surface area for foliar application with agrochemicals due to their huge surface area, and consequently, more uptake and permeability for a chemical substance to occur their action. After systemic chemical application substance entering in the plant to take place and exhibit their effect, plant deal with it as a xenobiotic and should be eliminate by metabolizing depending on chemical structure of xenobiotic and detoxification enzymes available inside plant, therefore, differentiation of metabolites according to plant. Some metabolites may have a hormonal or herbicidal effect, although, the parent compound don't have this effect as shown in Azoxystrobin fungicide which has no effect on sprayed plants while metabolites has a potential hormonal effect on tested plant which shown clearly on histological level. In this connection, our results showed improvements in most features measured in tomato leaflet and main stem with Azoxystrobin treatment under drought stress condition (Table 5, and Figs 1 and 2). It has been obviously exhibited that leaflet spongy and palisade tissues thickness correlated positively with Azoxystrobin treatments. Increased spongy and palisade tissues contain more chloroplasts that lead to a rise in photosynthesis and production of carbohydrates required to different plant activities. Photosynthesis activity requires more transpiration subsequently, more well water condition is crucial for hormonal activity of Azoxystrobin metabolites.

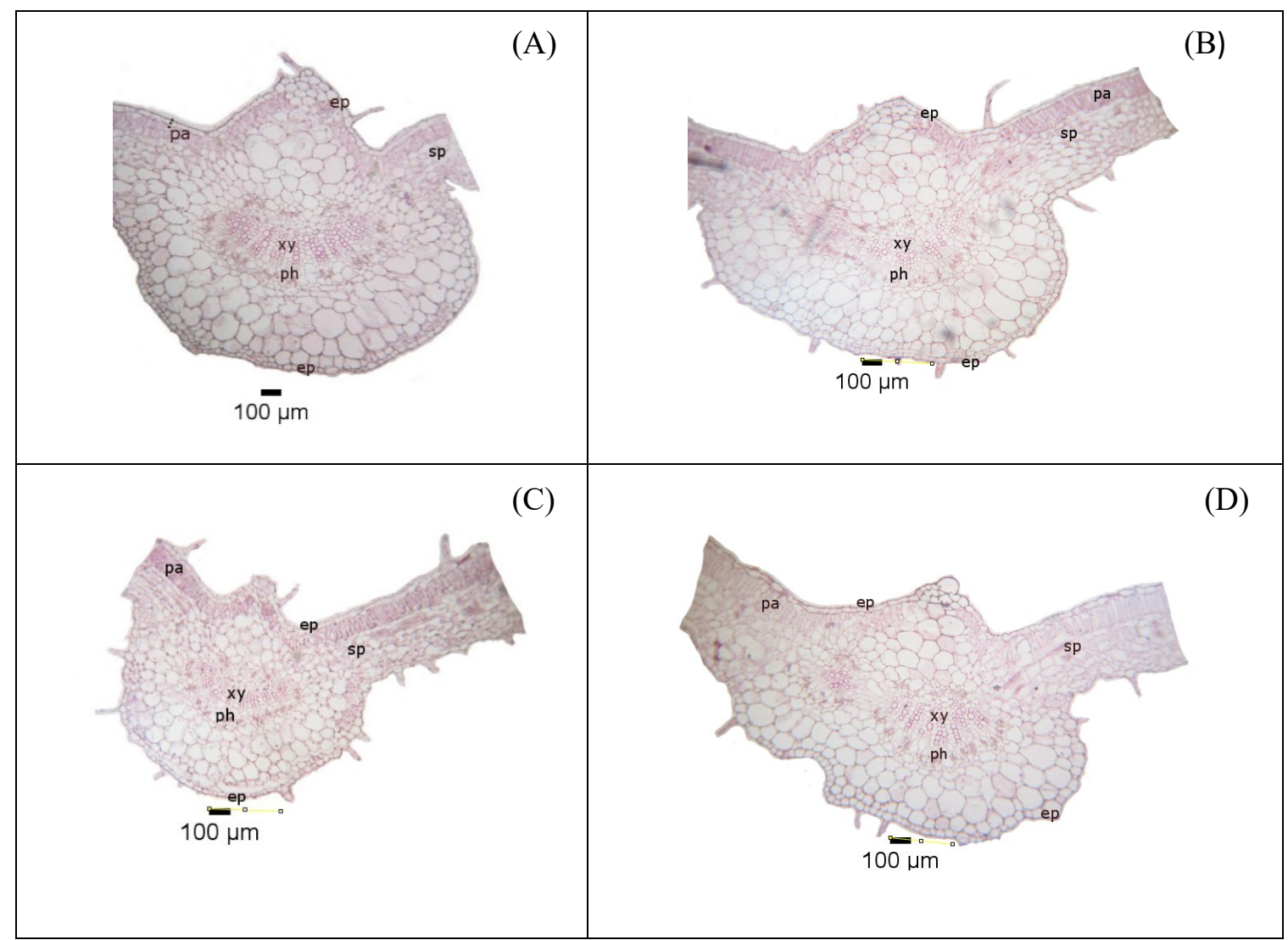

Figure 1. Cross section of tomato leaflet blade from: (A) well watered, (B) well watered + azoxystrobin, (C) drought condition, and (D) drought condition + azoxystrobin (ep means epidermis, pa means palisade tissue, sp means spongy tissue, ph means phloem tissue, and xy means xylem tissue) 


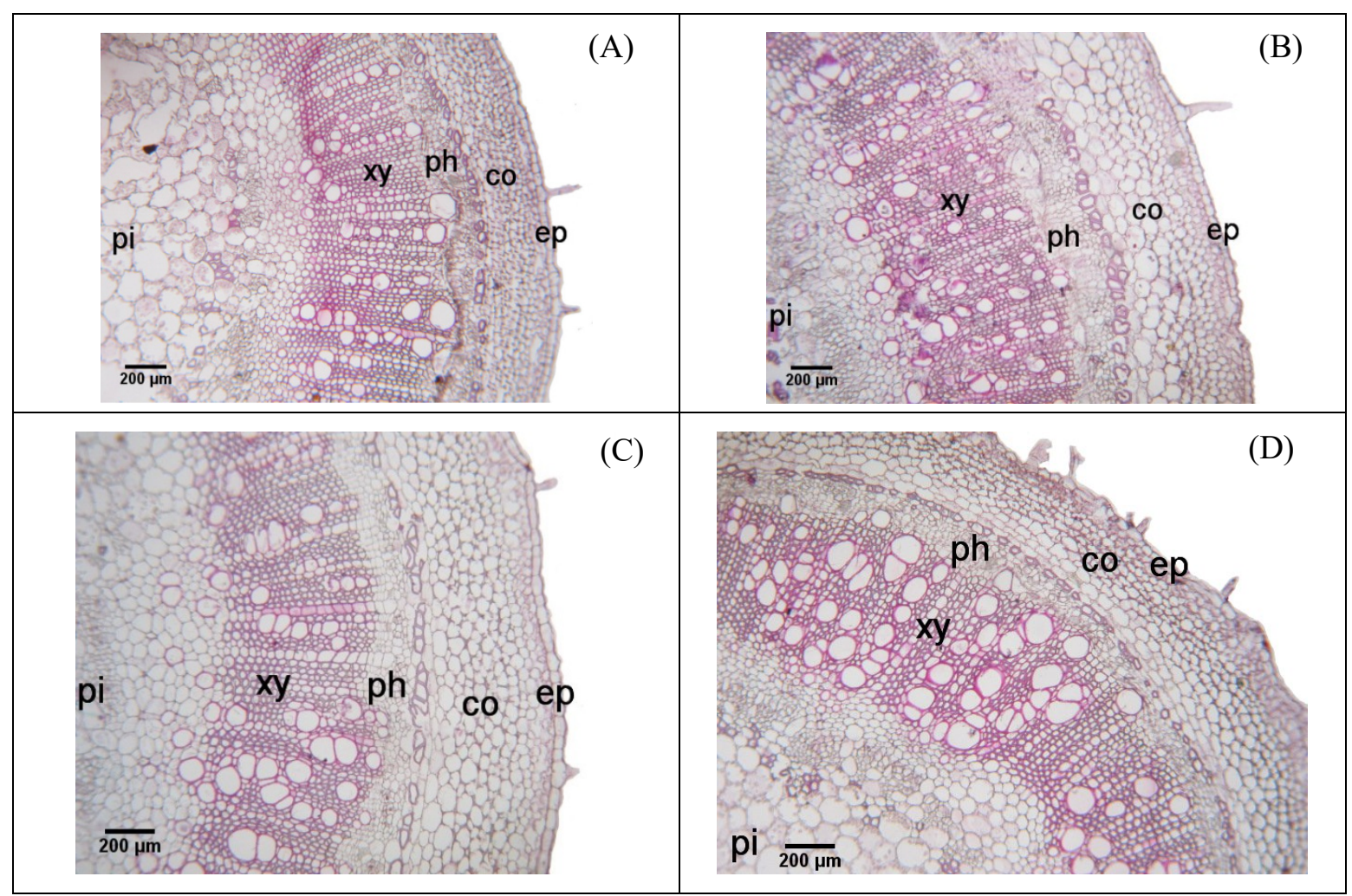

Figure 2. Cross section of tomato main stem from: (A) well watered, (B) well watered + azoxystrobin, (C) drought condition, and (D) drought condition + azoxystrobin

(ep means epidermis, co means cortex, ph means phloem tissue, xy means xylem tissue, and pi means pith)

\section{Conclusion}

Azoxystrobin fungicide application was found, in this study, to be pivotal important anti-stress ameliorating drought effects. This was shown through increasing osmoprotectants, antioxidants and photosynthetic efficiency and reducing tomato plant size to reduce water loss from drought stressedtomato plants, and this was gathered with increasing total root volume by Azoxystrobin application to increase the root capacity to absorb more water under drought stress. These results were reflected in increased root dry weight and maintained plant dry weight to increase the final fruit yield of tomato plant under the studied stress.

\section{Acknowledgement}

Thanks to Prof. Dr. Mohamed-Bassem Ali Ashour, for helping with the academic technical support to finish this work with honourable way.

\section{References}

[1] M.M. Peet, Irrigation and fertilization, in: E. Heuvelink (Ed.), Tomatoes, Crop Production Science in Horticulture. CABI Publishing, UK, 2005, pp. 171-198.

[2] J.H. Leiminger, H. Hausladen, Effect of different fungicides on the control of early blight (Alternaria spp.) and potato yield. Gesunde Pflanzen, 63(1) (2011) 11-18.

[3] D.W. Bartlett et al., The strobilurin fungicides, Pest Manag. Sci. 58(7) (2002) 649-662.

[4] P. Beaumont, Azoxystrobin, Pesticides News. 51 (2001) 21. 
[5] V. Anthony et al., Strategies for fungal control-development of fungicides or use biotechnology? Mededelingen - Faculteit Landbouwkundige en Toegepaste Biologische Wetenschappen, Universiteit Gent. 63(4b) (1998) 1619-1624.

[6] L. Dacol et al., Azoxystrobin: development on horticultural crops in Europe. Proceedings of an International Conference, Brighton Crop Protection Conference: Pests \& Diseases, 16-19 November 1998, UK, 3 (1998) 843-848.

[7] P. Siviero et al., Efficacy of a new fungicide for industrial tomatoes, Informatore Agrario. 56(8) (2000) 104-106.

[8] M.M. Giuliani et al., Processing tomato cultivated under water deficit conditions: the effect of azoxystrobin, Acta Hortic. 914 (2011) 287-294.

[9] V. Cantore et al., Combined effect of deficit irrigation and strobilurin application on yield, fruit quality and water use efficiency of "cherry" tomato (Solanum lycopersicum L.). Agric. Water Manag. 167(2016) 53-61.

[10] R. Charles, Modelling pesticides residues. Ph.D. Thesis. Federal Institute of Technology in Lausanne, Faculty Natural Environment, Architectural and Constructed, Institute of Environmental Science and Technology, Science and Environmental Engineering Section, Lausanne, Epfl, Switzerland, (2004).

[11] A.A.I. Ali et al., Azoxystrobin residues on tomato leaves and fruits, Zagazig J. Agric. Res. 42(6) (2015) 1547-1553.

[12] C.Y. Sullivan, Sorghum in the Seventies: Mechanism of Heat and Drought Resistance in Grain Sorghum and Methods of Measurement, Sorghum in the Seventies. Rao, N.G.P., House, L.R., Eds, New Delhi, India: Oxford and IBH Publ. Co., (1972) 247-264.

[13] N.C. Turner, Crop Water Deficit: A Decade of Progress, Adv. Agron. 39 (1986) 1-51.

[14] E. Farshadfar et al., Inheritance of drought tolerance in maize, Cer. Res. Commun. 30 (2002) 3-4.

[15] P. Gavuzzi et al., Evaluation of field and laboratory predictors of drought and heat tolerance in winter cereals, Can. J. Plant Sci. 77 (1997) 523-531.

[16] A.A. Fadeel, Location and properties of chloroplasts and pigment determined in shoots, Plant Physiol. 15 (1962) 130-137.

[17] Z. Sestak et al., Determination of chlorophylls a and b, in: Z. Sestak, J. Catsky, P.G. Jarvis (Eds.), Plantphotosynthetic production: Manual of Methods. (1971) 672-697. The Hague: Junk.

[18] L.S. Bateset al., Rapid determination of free proline for water stress studies, Plant Soil. 39 (1973) 205-207.

[19] R.N. Feinstien, Proborate as substrate in a new assay of catalase, J. Bio. Chem. 180 (1949) 1197-1202.

[20] R. Hammerschmidt et al., Association of enhanced peroxidase activity with induced systemic resistance of cucumber to Colletotrichum lagenarium, Physiol. Plant Pathol. 20 (1982) 73-82.

[21] J. Kochba et al., Difference in peroxidase activity and isozymes in embryogenic and nonembryogenic 'sharr outi' orange ovular callus lines, Plant Cell Physiol. 18(46) (1977) 3-7.

[22] A.M. Mayer et al., Assay of catecholoxidase a critical comparison of methods, Phytochem. 5 (1965)783-789.

[23] R. Snell, G. Snell, Colorimetric Method of Analysis. Vol. III. $3^{\text {rd }}$ ed., New York, D. van Nostrand Company Inc.,( 1953) 225-233. 
[24] M.A. Nassar, K.F. El-Sahhar, Plant Microtechnique. Academic Bookshop, Egypt, (1998) 224 (In Arabic).

[25] K.A. Gomez, A.A. Gomez, Statistical Procedures for Agricultural Research, Wiley International Science Publication, John Wiley and Sons, New York, NY, USA, 1984, 680 p.

[26] S.P. Kiani et al., Genetic analysis of plant water status and osmotic adjustment in recombinant inbred lines of sunflower under two water treatments, Plant Sci. 172 (2007) 773-787.

[27] M. Farooq et al., Advances in drought resistance of rice, Crit. Rev. Plant Sci. 28 (2009) 199217.

[28] L. Taiz, E. Zeiger, Plant Physiology, $5^{\text {th }}$ edn. Sinauer Associates Inc. Publishers, Massachusetts (2010).

[29] F. Liu et al., Drought stress effect on carbohydrate concentration in soybean leaves and pods during early reproductive development: its implication in altering pod set, Field Crops Res. 86 (2004) 1-13.

[30] O. Ozkur et al., Physiochemical and antioxidant responses of the perennial xerophyte Capparis ovata Desf. to drought, Environ. Exp. Bot. 66 (2009) 487-492.

[31] A.R. Reddy et al., Drought-induced responses of photosynthesis and antioxidant metabolism in higher plants, J. Plant Physiol. 161 (2004) 1189-1202.

[32] J. Flexas, H. Medrano, Energy dissipation in $\mathrm{C}_{3}$ plants under drought, Funct. Plant Biol. 29 (2002) 1209-1215.

[33] O. Ghannoum, $C_{4}$ photosynthesis and water stress, Ann. Bot. 103 (2009) 635-644.

[34] G. Noctor et al., Photorespiratory glycine enhances glutathione accumulation in both the chloroplastic and cytosolic compartments, J. Exp. Bot. 50 (1999) 157-1167.

[35] A. Wingler et al., Photorespiration: metabolic pathways and their role in stress protection, Philos. Trans. R Soc. Lond. B Biol. Sci. 355 (2000) 1517-1529.

[36] K., Apel, H. Hirt, Reactive oxygen species: metabolism, oxidative stress, and signal transduction, Annu. Rev. Plant Biol. 55 (2004) 373-399.

[37] M. Farooq et al., Heat stress in wheat during reproductive and grain filling phases, Crit. Rev. Plant Sci. 30 (2011) 491-507.

[38] S.S. Gill, N. Tuteja, Reactive oxygen species and antioxidant machinery in abiotic stress tolerance in crop plants, Plant Physiol. Biochem. 48 (2010) 909-930.

[39] A. Blum, Drought resistance, water-use efficiency, and yield potential - are they compatible, dissonant, or mutually exclusive?, Aust. J. Agric. Res. 56 (2005) 1159-1168.

[40] T. Kavar e al., Identification of genes involved in the response of leaves of Phaseolus vulgaris to drought stress, Mol. Breed. 21 (2007) 159-172.

[41] M. Broin et al., Involvement of CDSP 32, a drought-induced thioredoxin, in the response to oxidative stress in potato plants, FEBS Lett. 467 (2000) 245-248.

[42] S.D. Tyerman et al., Plant aquaporins: multifunctional water and solute channels with expanding roles, Plant, Cell Environ. 25 (2002) 173-194.

[43] P.K. Agarwal et al., Role of DREB transcription factors in abiotic and biotic stress tolerance in plants, Plant Cell Rep. 25 (2006) 1263-1274.

[44] M. Seki et al., Molecular responses to drought, salinity and frost: common and different paths for plant protection, Curr. Opin. Biotechnol. 14 (2003) 194-199. 
[45] D-S. Gong et al., Early activation of plasma membrane $\mathrm{H}^{+}$-ATPase and its relation to drought adaptation in two contrasting oat (Avena sativa L.) genotypes, Environ. Exp. Bot. 69 (2010) 18.

[46] H. Bae et al., The drought response of Theobroma cacao (cacao) and the regulation of genes involved in polyamine biosynthesis by drought and other stresses, Plant Physiol. Biochem. 46 (2008) 174-188.

[47] S. Nithyameenakshi et al., Investigations on phytotoxicity of two new fungicides, azoxystrobin and difenoconazole, Amer. J. Plant Physiol. 1(1) (2006) 89-98.

[48] A.M. Nason et al., Strobilurin fungicides induce changes in photosynthetic gas exchange that do not improve water use efficiency of plants grown under conditions of water stress, Pest Manag. Sci. 63(12) (2007) 1191-1200.

[49] M. Wilkinson, Metabolism of azoxystrobin in Winter Wheat. Jealott's Hill Research Station, Zeneca Agrochemicals, UK. Report No. RJ1682B.Syngenta File No. ICI5504/0286(1994).

[50] J. Webb, Metabolism of azoxystrobin in Peanuts. Jealott's Hill Research Station, Zeneca Agrochemicals, UK. Report No. RJ1807B. Syngenta File No. ICI5504/1273 (1995).

[51] A. Patel, Azoxystrobin: metabolism in cotton following an in-furrow application. Jealott's Hill Research Station, Zeneca Agrochemicals Syngenta File No. ICI5504/0283, Syngenta Report No. RJ2695B (1999).

[52] C. Swoboda, P. Pedersen, Effect of fungicide on soybean growth and yield, Agron. J. 101 (2009) 352-356.

[53] E.B. Fagan et al., Efeito da aplicac, ão depiraclostrobinana taxa fotossintética, respirac, ão, atividade da enzimanitrato redutase eprodutividade degrãos de soja, Bragantia, Campinas, (2010) 771-777.

[54] J. Joshi et al., Foliar application of Pyraclostrobinfungicide enhances the growth, rhizobialnodule formation and nitrogenaseactivity in soybean (var. JS-335). Pestic. Biochem. Physiol. 114 (2014) 61-66.

[55] L.A. Kozlowski et al., Physiological effects of strobilurins F 500Reg. in the growth and yield of bean, Revista Academica Ciencias Agrariase Ambientais 7(1) (2009) 41-54.

[56] M.M. Giuliani et al., Water stress in tomatoes, the role of fungicide treatments. Informatore Agrario 62(11) (2006) 52-54.

[57] A. Watson et al., Aphanomyces root rot of beans and control options, Aust. Plant Pathol. 42(3) (2013) 321-327. 